\title{
The application of polymerase chain reaction-denaturing gradient gel electrophoresis (PCR-DGGE) method in microbial screening
}

\author{
Tingtao Chen ${ }^{1}$, Mengjuan Wang ${ }^{1}$, Shuying Jiang ${ }^{1}$, Shunqiang Xiong ${ }^{1}$ and Hua Wei ${ }^{1,2 \star}$ \\ ${ }^{1}$ State Key Laboratory of Food Science and Technology, Nanchang, Jiangxi, 330047, China. \\ ${ }^{2}$ Jiangxi-OAI Joint Research Institute, Nanchang University 235 Nanjing Donglu, Nanchang, Jiangxi, 330047, P.R. China.
}

Accepted 23 May, 2011

A rapid microbial screening method was developed based on denaturing gradient gel electrophoresis (DGGE). To evaluate the repeatability and reliability of this system, three DGGE markers were used. Then, the feasibility of DGGE method was verified by microbial screenings in viili (a traditional fermented dairy product originated from Scandinavia) and sourdoughs. The results suggested that, this method could efficiently classify the duplicate strains isolated from the complex environment and identify their dominance in microbial ecology if the corresponding environment samples had been provided. This paper proposed the application of polymerase chain reaction (PCR)-DGGE method in reducing the complicated work in microorganism identifications or even directly identified the target strains if a proper DGGE marker had been applied.

Key words: Denaturing gradient gel electrophoresis (DGGE), microbial screening, bacteria, fungi, Lactobacillus, bifidobacteria, sourdoughs, viili.

\section{INTRODUCTION}

It is a fact that lots of microorganisms exist in water, food, animal intestine and soil. For various reasons, we need to isolate these strains from the complex environment and study their characteristics. However, microorganisms isolated and selected empirically by taxonomists is somewhat restricted because of repetitive encounters with possible duplicate strains (Fujimori and Okuda, 1994). In addition, when similar strains are passed through a certain assay system based on their activity, it is difficult to determine whether one of them should be eliminated for it takes time to examine these precisely. To improve the efficiency in elimination progress, we applied the denaturing gradient gel electrophoresis (DGGE) method in microbial screening. Compared with the traditional

*Corresponding author. E-mail: hua_wei114@yahoo.com.cn. Fax: +86-791-8333708

Abbreviations: DGGE, Denaturing gradient gel electrophoresis; LAB, lactic acid bacteria; MRS, Man, Rogosa and Sharpe; YPD, yeast peptone dextrose; PCR, polymerase chain reaction. method, DGGE method does not require microbial cultivation and allows the analysis of DNA extracted directly from the sample (Bastias et al., 2007) and can identify single-nucleotide changes in a segment of DNA. Above all, information about the bacterial profiles of the sample can be achieved within $24 \mathrm{~h}$ (Temmerman et al., 2004). Till now, DGGE has been widely used for detection of the total microbial/specific bacterial population and diversity in samples (Giraffa, 2004; Hovda, 2007; Liu et al., 2010).

In this study, the DGGE method was applied to distinguish the duplicate strains isolated from environmental samples by using universal or specific primers whose amplifications were limited to $400 \mathrm{bp}$. The microorganisms possessing the same band number and locations in DGGE gel are considered as one species which was then identified by using full-length sequence. This technology proves a rapid microbial screening method to discern the same strain in samples, which reduces work load in the following identification process by using traditional and/or molecular methods. In addition, if the microorganisms isolated were consistent with the bacteria used to make 
Table 1. PCR primers used in this study.

\begin{tabular}{|c|c|c|c|}
\hline Target organism & Primer & Sequence $\left(5^{\prime} \rightarrow 3^{\prime}\right)$ & Reference \\
\hline \multirow[t]{3}{*}{ Bacteria } & $27(F)$ & AGAGTTTGATCCTGGCTCAG & \multirow[t]{2}{*}{ Lane (1991) } \\
\hline & $1492(\mathrm{R})$ & GGCTACCTTGTTACGACTT & \\
\hline & $338(\mathrm{R})^{+}$ & GGACTCCTACGGGAGGCAGCAG & Muyzer et al. (1993) \\
\hline \multirow[t]{4}{*}{ Fungi } & NS1 (F) & GTAGTCATATGCTTGTCTC & \multirow{4}{*}{$\begin{array}{l}\text { Vainio and Hantula } \\
\text { (2000) }\end{array}$} \\
\hline & FR1 (R) & AICCATTCAATCGGTAIT & \\
\hline & FF390(F) & CGATAACGAACGAGACCT & \\
\hline & $\mathrm{FR} 1(\mathrm{R})^{+}$ & CCGAICCATTCAATCGGTAIT & \\
\hline \multirow[t]{2}{*}{ Lactobacilli } & $\operatorname{lac} 1(\mathrm{~F})$ & AGCAGTAGGGAATCTTCCA & \multirow{2}{*}{ Endo et al. (2009) } \\
\hline & $\operatorname{lac} 2(\mathrm{R})^{+}$ & ATTY CACCGCTACACATG & \\
\hline \multirow[t]{2}{*}{ Bifidobactrium } & Bifid (F) & CTCCTGGAAACGGGTGG & \multirow{2}{*}{ Lubbs et al. (2009) } \\
\hline & Bifid $(\mathrm{R})^{+}$ & GGTGTTCTTCCCGATATCTACA & \\
\hline
\end{tabular}

F, Forward primer; R, reverse primer; +, GC clamp (CGCCCGGGGCGCGCCCCGGGCGGGGCGGGGGCAC GGGGG).

DGGE marker, we can directly identified them according to their band numbers and locations.

\section{MATERIALS AND METHODS}

\section{Strains and samples}

\section{Bacteria strains and growth conditions}

The strains Bifidobacteria longum NCC2705, Lactobacillus rhamnosus ATCC7469, Lactobacillus salivarius subsp. salivarius ATCC11741, Lactobacillus acidophilus ATCC4356, Lactobacillus plantarum ATCC8014, Bifidobacteria infantis C2, Bifidobacteria adolenscent BA1, Streptococcus thermophilusG1 were used as control strains in making DGGE markers. Lactobacilli were cultured in a modified atmosphere $\left(2 \% \mathrm{O}_{2}, 10 \% \mathrm{CO}_{2}\right.$ and $\left.88 \% \mathrm{~N}_{2}\right)$ at 30 or $37^{\circ} \mathrm{C}$ on MRS5 medium (Meroth et al., 2003).

\section{Viili starter and isolates}

In the laboratory, viili starter was incubated (5\%, wt/vol) and propagated in sterilized milk at $25^{\circ} \mathrm{C}$ for $20 \mathrm{~h}$, then the starter was transferred into fresh milk and incubated at $25^{\circ} \mathrm{C}$ for another $20 \mathrm{~h}$. This procedure was repeated 3 times after which the starter was considered active and used in this study. Then, $10 \mathrm{~g}$ of viili starter was homogenized in $90 \mathrm{ml}$ of sterile saline solution $(0.85 \%$ sodium chloride solution, $\mathrm{pH}$ 5.5) in a stomacher and concentrations of the viable bacteria in suspensions were obtained by serial plating dilutions. The total bacteria in viili were examined on $\mathrm{BHI}$ agar (Jacobsen, 1999) and LB+ skimmed milk agar; the lactic acid bacteria (LAB) were examined on Man, Rogosa and Sharpe (MRS) agar (Todorov and Engell, 2008).

\section{Sourdough fermentation and sampling}

Fermentations were started by adding three commercial sourdough starters (Fabao, Anqi and Distiller's grains) available for industrial use. Sourdoughs of type II were obtained through continuous propagation by back-slopping of ripe dough for 12 days and the ripe sourdough was used as an inoculum for the subsequent fermentation cycle every $24 \mathrm{~h}$. The total bacteria in sourdough fermentations were examined on BHI agar (Jacobsen, 1999) and Yeast peptone dextrose (YPD) agar (Yaffe and Schatz, 1984) for fungi.

\section{DNA extraction and PCR amplification}

DNA was isolated according to a bead-beating method (Zoetendal et al., 1998). Samples were suspended in $1 \mathrm{ml}$ TN150 buffer containing $10 \mathrm{mM}$ Tris- $\mathrm{HCl}(\mathrm{pH} 8.0)$ and $150 \mathrm{mM} \mathrm{NaCl}$ in a screw-capped tube, containing $0.3 \mathrm{~g}$ of sterile zirconium beads (diameter, $0.1 \mathrm{~mm}$ ) and $150 \mu \mathrm{l}$ of phenol. The tubes were bead-beaten at $5000 \mathrm{rpm}$ for $3 \mathrm{~min}$ in a mini-bead beater, following phenol-chloroform extraction. The solution was precipitated with ethanol and pellets were suspended in $500 \mu \mathrm{l}$ of TE. This solution was added to $5 \mathrm{U}(1 \mu \mathrm{l})$ of Dnase-free Rnase and incubated at $37^{\circ} \mathrm{C}$ for $15 \mathrm{~min}$. After phenol-chloroform extraction, DNA was precipitated with ethanol and suspended in $50 \mu$ of TE.

Primers used in this study are shown in Table 1. Polymerase chain reaction (PCR) was performed with the Taq DNA polymerase kit from life technologies. Based on the instruction of manufacturer, the PCR reaction $(25 \mu \mathrm{l})$ used $0.125 \mu \mathrm{l}$ of Tap polymerase $(1.25 \mathrm{U})$, $0.5 \mu \mathrm{l}$ of primers, $1 \mu \mathrm{l}$ of ten-fold diluted DNA template (approximately $1 \mathrm{ng}$ ), $2.5 \mu \mathrm{l}$ of ten-fold PCR buffer, $1.5 \mu \mathrm{l}$ of $\mathrm{MgCl}_{2}$ $(50 \mathrm{mM})$ and lastly UV-sterile water. The samples were amplified in a Biosci PCR system, with 30 cycles of $94^{\circ} \mathrm{C}$ for $30 \mathrm{~s}, 56^{\circ} \mathrm{C}$ for $30 \mathrm{~s}$ and $72^{\circ} \mathrm{C}$ for $60 \mathrm{~s}$. Aliquots of $5 \mu \mathrm{l}$ were analyzed by electrophoresis on an agarose gel (1\%) to check the size of the amplicons.

\section{DGGE gel}

Amplicons of V3 of 16S rDNA were used for sequence-separation by DGGE (Simpson, et al., 2004). DGGE was performed using 40 $\mathrm{mM}$ Tris- $\mathrm{HCl}(\mathrm{pH} 8.0)$ as the electrophoresis buffer in a BioRad DGGE system. The electrophoresis was initiated by pre-running for $5 \mathrm{~min}$ at a voltage of $220 \mathrm{~V}$ and subsequently run at a fixed voltage 


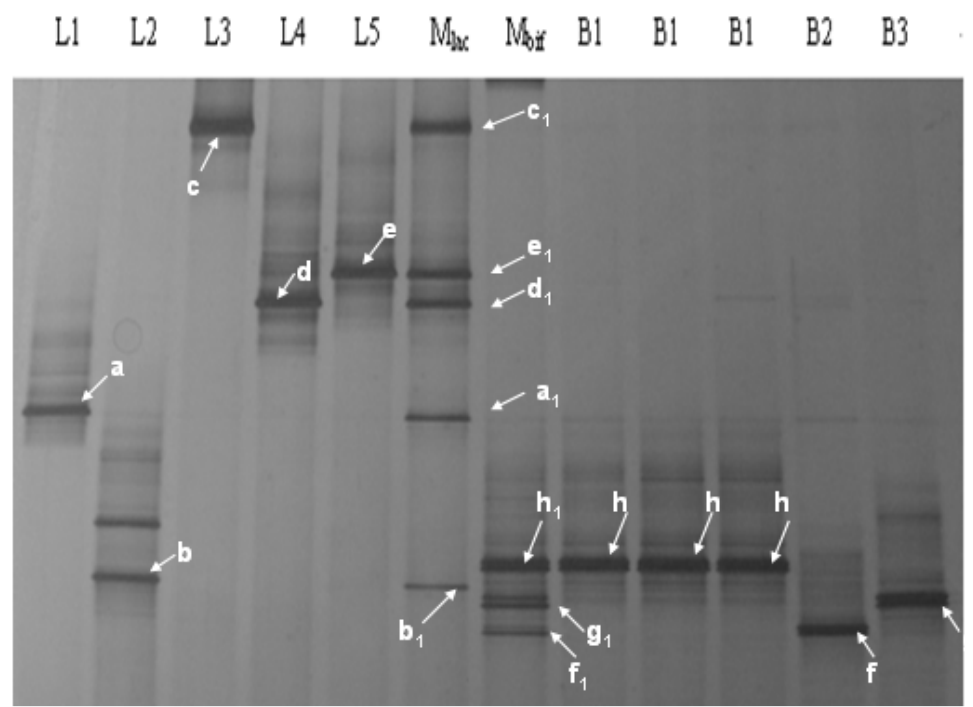

Figure 1. DGGE profiles of bacterial $16 \mathrm{~S}$ rDNA gene fragments amplified by bacteria universal primer $27(F) / 338 f(R)^{+} . L_{1}, \quad S$. thermophilus $\mathrm{G} 1, \mathrm{~L}_{2}$, L. rhamnosus ATCC7469; $\mathrm{L}_{3}, L$. plantarum ATCC8014; $L_{4}, L$. salivarius subsp. salivarius ATCC11741; $L_{5}, L$. acidophilus ATCC4356; $\mathrm{M}_{\mathrm{lac}}$, Lactobacilli marker; $\mathrm{M}_{\mathrm{bif}}$, Bifidobacteria marker; $\mathrm{B}_{1}$, Bifidobacteria longum NCC2705; $\mathrm{B}_{2}$, Bifidobacteria adolenscent $\mathrm{BA} 1 ; \mathrm{B}_{3}$, Bifidobacteria infantis $\mathrm{C} 2$.

of $85 \mathrm{~V}$ for $16 \mathrm{~h}$ at $60^{\circ} \mathrm{C}$. The gel was stained with $\mathrm{AgNO}_{3}$ and developed after completion of electrophoresis. The gel was then covered by cellophane membrane and dried overnight at $60^{\circ} \mathrm{C}$.

\section{Plasmid construction and sequencing}

PCR products were subcloned with the pMD18-T vector system 1 (Takara) according to the manufacturer's instructions. Cells of Escherichia coli were electrotransformed with recombinant plasmids by a standard method (Sambrook and Russell, 2001). Selection of transformants was done on LB agar containing $100 \mathrm{~g}$ of ampicillin per $\mathrm{ml}$. Transformants were randomly picked and sequenced (Invitrogen, Shanghai, China).

\section{Making of DGGE marker}

In order to check the feasibility of DGGE marker, PCR amplification of the 16S rDNA gene was performed using bacteria universal primer $27(\mathrm{~F}) / 338 \mathrm{f}(\mathrm{R})+($ Lane, 1991) and two DGGE markers (Mlac and $\left.\mathrm{M}_{\mathrm{bif}}\right)$ were made. The strains of interest were mixed to obtain final counts for each species of $5 \times 10^{7}$ and $5 \times 10^{8}$ cells $/ \mathrm{ml}$, DNA was extracted from a $1 \mathrm{ml}$ aliquot of the mixture and DGGE was carried out earlier. In addition, the corresponding amplification of single strain was also performed by DGGE method to determine the corresponding band in DGGE marker.

\section{RESULTS}

\section{DGGE marker design and verification}

In Figure 1, the $S$. thermophilusG1 $\left(L_{1}\right), \quad L$. rhamnosus
ATCC7469 $\left(L_{2}\right), \quad L$. plantarum ATCC8014 $\left(L_{3}\right), \quad L$. salivarius subsp. salivarius ATCC11741 $\left(L_{4}\right)$ and $L$. acidophilus ATCC4356 $\left(\mathrm{L}_{5}\right)$ in DGGE gel could find the corresponding bands from $\mathrm{M}_{\mathrm{lac}}$, respectively. Also, the same results were observed from $M_{\text {bif. }}$ To confirm the results, the primers lac1 (F)/ lac2 $(R)^{+}$(Endo et al., 2009) and Bifid (F)/Bifid $(R)^{+}$(Lubbs et al., 2009) specific for Lactobacilli and Bifidobacteria were applied. Figure 2 shows that, the repeated $B$. longum NCC2705 $\left(B_{1}\right)$ used in $M_{\text {bif }}$ making had successfully verify the repeatability of DGGE method and the amplification failure of $S$. thermophilusG1 $\left(\mathrm{L}_{1}\right)$ also verified the high specific of Lactobacilli primer lac1 $(\mathrm{F}) /$ lac2 $(\mathrm{R})^{+}$.

\section{The microbial screening from viili}

The bacteria in viili were mainly composed of $L A B$ and yeasts. As the yeast species and distributions in viili had been comprehensively studied (Wang et al., 2008), so only the bacteria were evaluated in this study.

In order to lower the chances of amplification failure, both universal and Lactobacilli specific primers were applied. Results of the PCR amplification (Figure 3a) showed that, all the strains could be amplified (about 200 bp) by $V_{3}$ universal primers which ensured the quality of bacterial DNAs; when Lactobacilli specific primers were used to amplify the same DNAs, no bands were found in lanes 3, 4, 9, 11, 13, which indicated that, the strains 2, 3, 8, 10 and 12 belong to bacteria other than Lactobacilli. In 


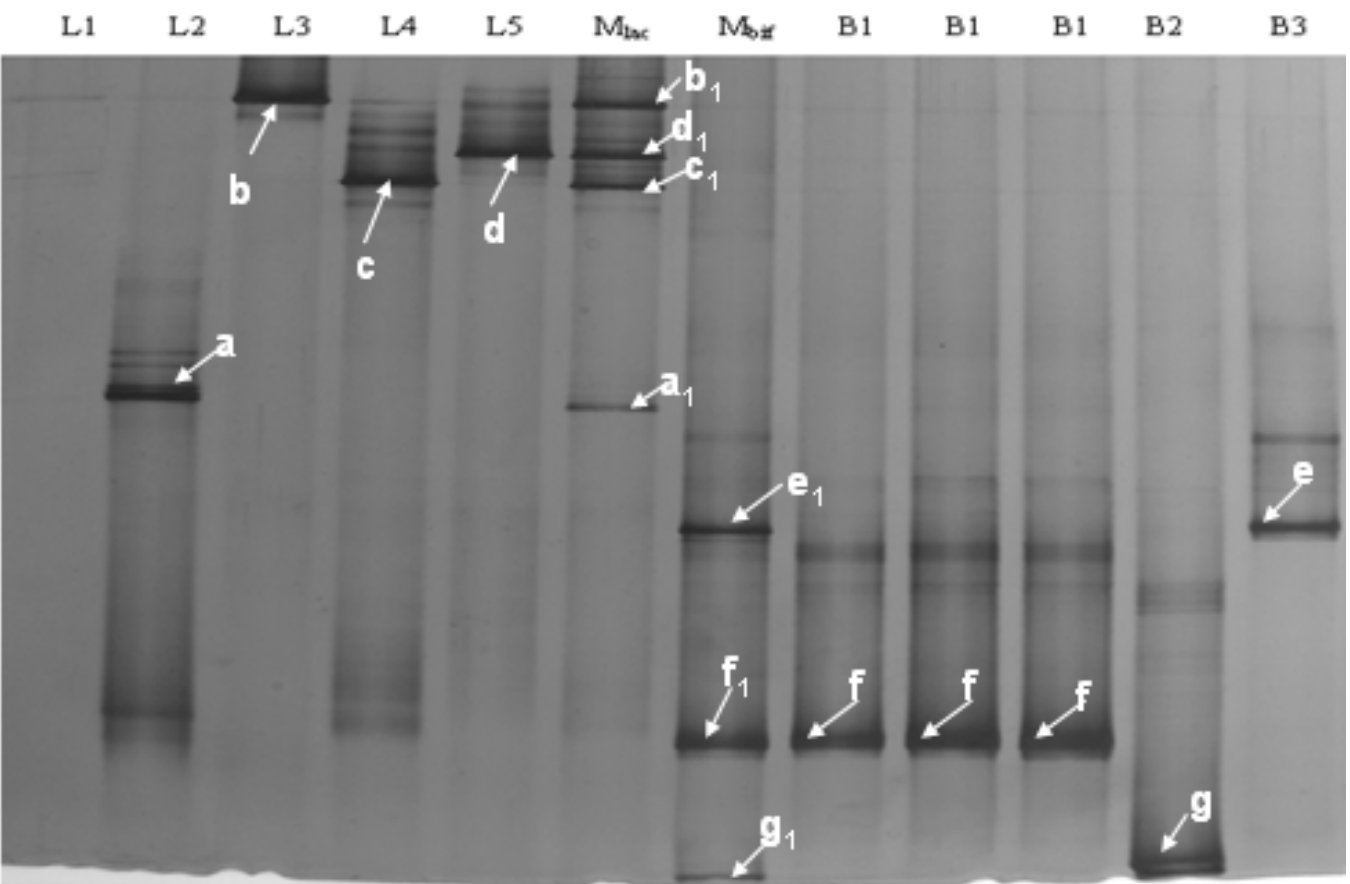

Figure 2. DGGE profiles of bacterial $16 \mathrm{~S}$ rDNA gene fragments amplified by Lactobacilli specific primer lac $1(\mathrm{~F}) /$ lac2 $(\mathrm{R})^{+}$and Bifidobacteria specific primer Bifid $(\mathrm{F}) /$ Bifid $(\mathrm{R})^{+}{ } \mathrm{L}_{1}, \mathrm{~S}$. thermophilus $\mathrm{G} 1, \mathrm{~L}_{2}, L$. rhamnosus ATCC7469; $L_{3}$, L. plantarum ATCC8014; $L_{4}$, L. salivarius subsp. salivarius ATCC11741; $L_{5}$, $L$. acidophilus ATCC4356; $\mathrm{M}_{\mathrm{lac}}$, Lactobacilli marker; $\mathrm{M}_{\mathrm{bif}}$, Bifidobacteria marker; $\mathrm{B}_{1}$, $B$. longum NCC2705; $\mathrm{B}_{2}, B$. adolenscent BA1; $\mathrm{B}_{3}, B$. infantis $\mathrm{C} 2$.
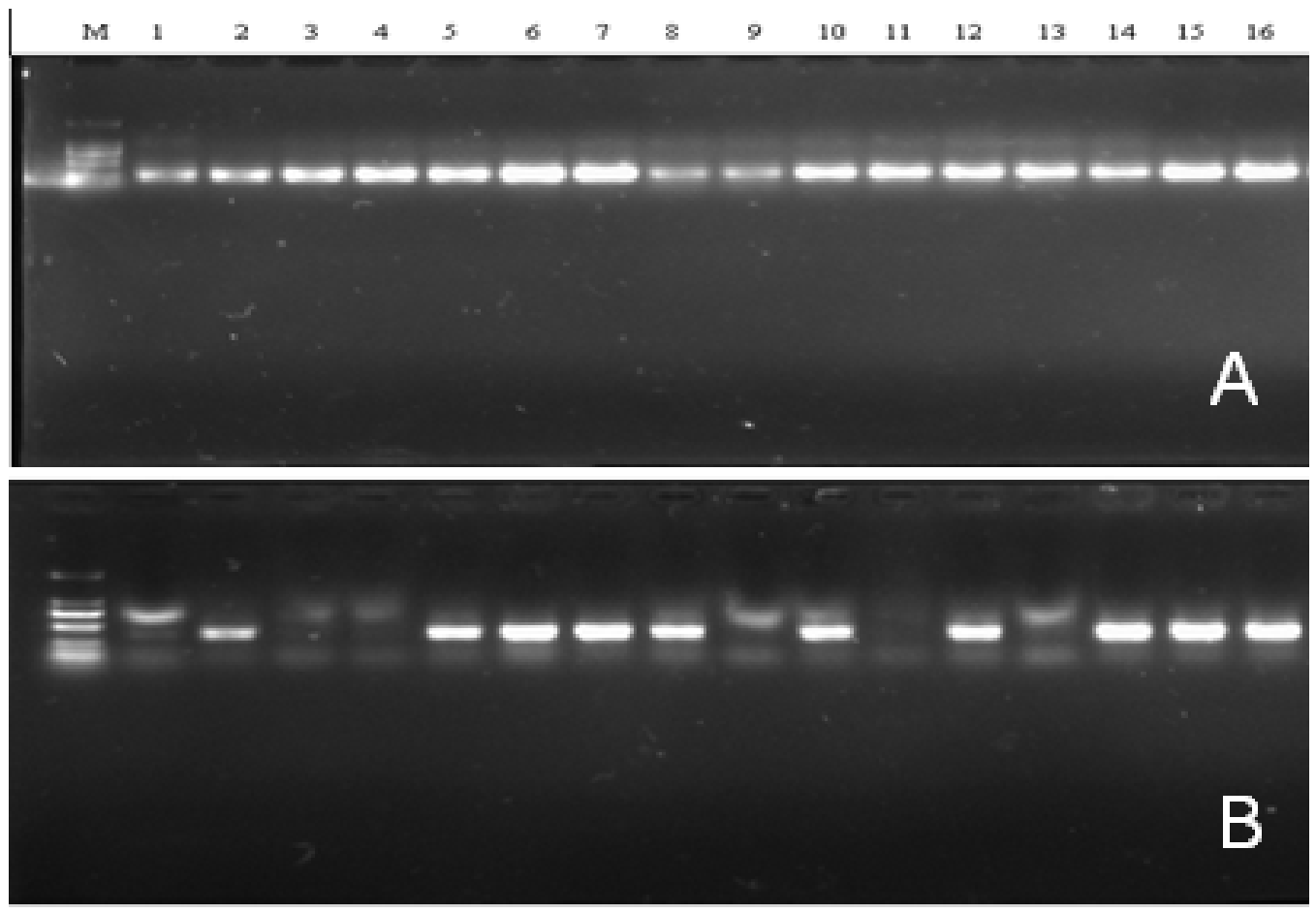

Figure 3. The profile of PCR amplification. (A) The PCR amplification of total bacteria (about $193 \mathrm{bp}$ ); (B) the PCR amplification of Lactobacilli (about $380 \mathrm{bp}$ ); M, DL2000 DNA Marker (from top to bottom: 2000, 1000, 750, 500, 250 and $100 \mathrm{bp}$ ); 1, viili; 2 to 16 , strains 1 to 15. 


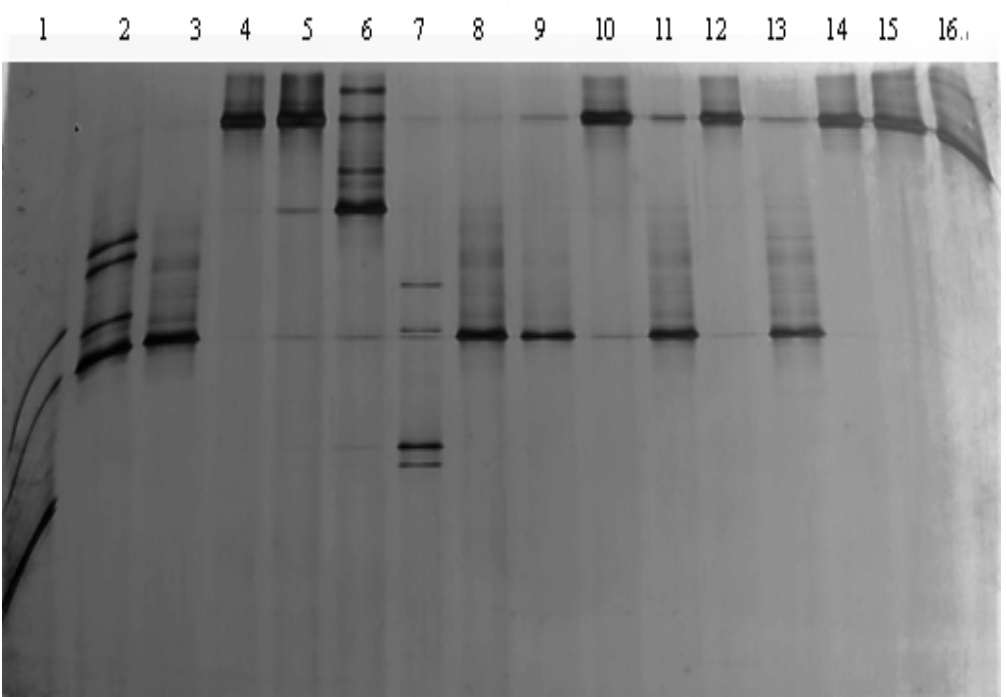

Figure 4. DGGE profiles of bacterial 16S rDNA gene fragments amplified from viili by using bacteria universal primer $27(F) / 338 f(R)^{+} .1-7$, strains 1 to $7 ; 8$, viili; 9 to 16 and strains 8 to 15 .

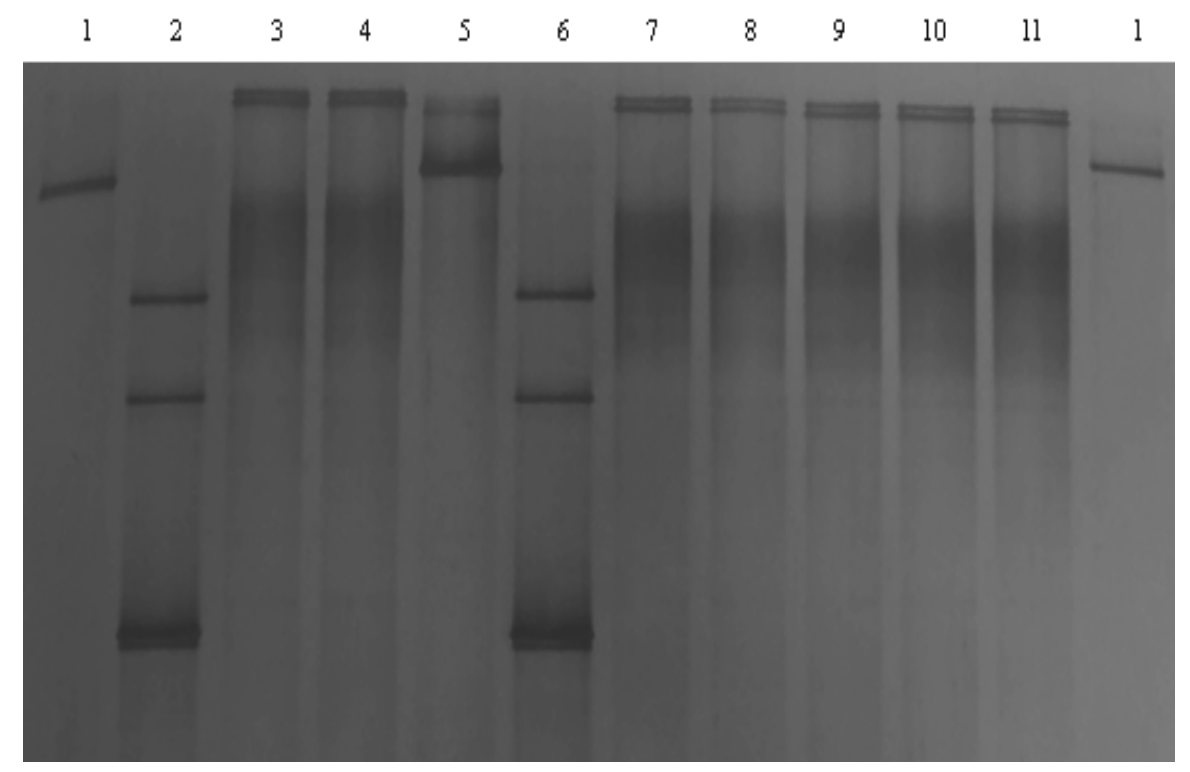

Figure 5. DGGE profiles of bacterial 16S rDNA gene fragments amplified from viili by using Lactobacilli specific primer lac1 $(F) /$ lac2 $(R)+$. 1, viili; 2 to 11; strains 1, 4, 5, 6, 7, 9, 11, 13, 14 and 15.

the next step, DGGE method was used to distinguish the same bacteria isolated. In Figure 4, the dominate bands in lanes 1 and 7 shared the same location in DGGE gel which indicated that, they belonged to the same bacterium; likewise, the strains $4,5,9,11,13,14$ and 15; $3,8,10$ and 12 belonged to same strain, respectively. As the dominant bands of strain 2 and 6 were different from the other bacteria, so they were distinctive. Moreover, the dominant band in vili (band 8) shared the same locations with strains $3,8,10$ and 12, which indicated that, the dominant strain in villi belongs to these genera. In Figure 5 , the strains 1 and 7 shared the same dominant band locations in DGGE gel, they belonged to a same Lactobacillus. From the earlier mentioned, strains 4, 5, 9, $11,13,14$ and 15 were a (from the) same Lactobacillus, while strain 6 was a different Lactobacillus. In the gel, the dominant band of viili were located on same position with strain 6, so the dominant Lactobacillus in villi is the real 
Table 2. $16 \mathrm{~S}$ rDNA sequencing results of isolates in viili distinguished by denaturing gradient gel electrophoresis (DGGE) method.

\begin{tabular}{llcc}
\hline Stain no. & Closest relatives & Similarity (\%) & GeneBank no. \\
\hline Strain 2 & Bacillus cereus & 100 & AM944031.1 \\
Strain 6 & Lactobacillus delbrueckii & 100 & FJ915705.1 \\
Strain 7 & Lactobacillus paracasei & 100 & FJ861111.1 \\
Strain 10 & Streptococcus thermophilus & 100 & EU149656 \\
Strain 14 & Lactobacillus plantarum & 100 & EU552039.1 \\
\hline
\end{tabular}

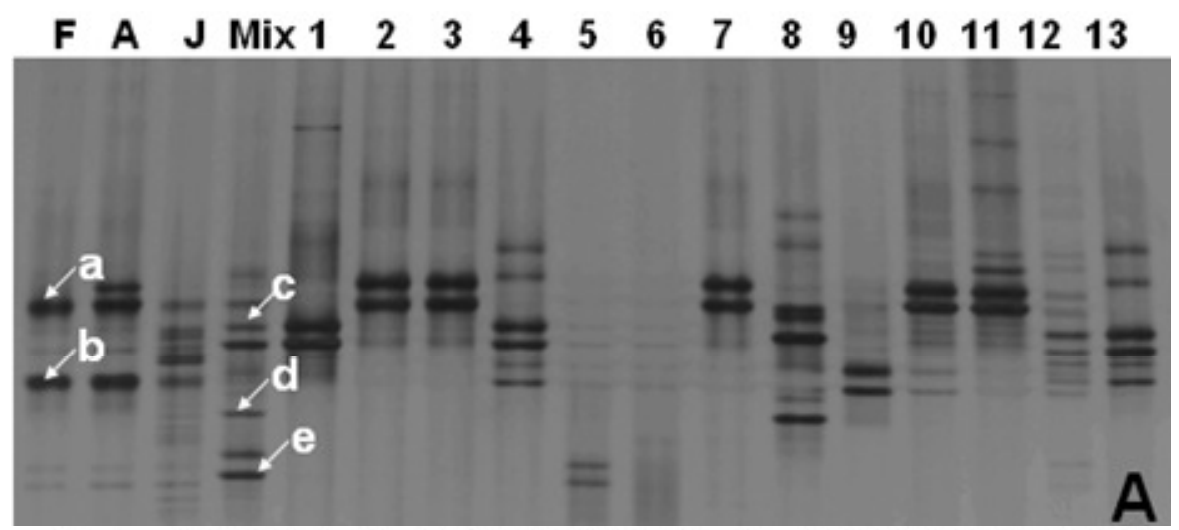

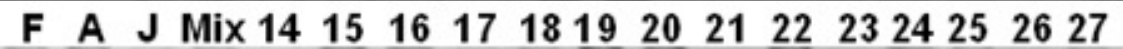

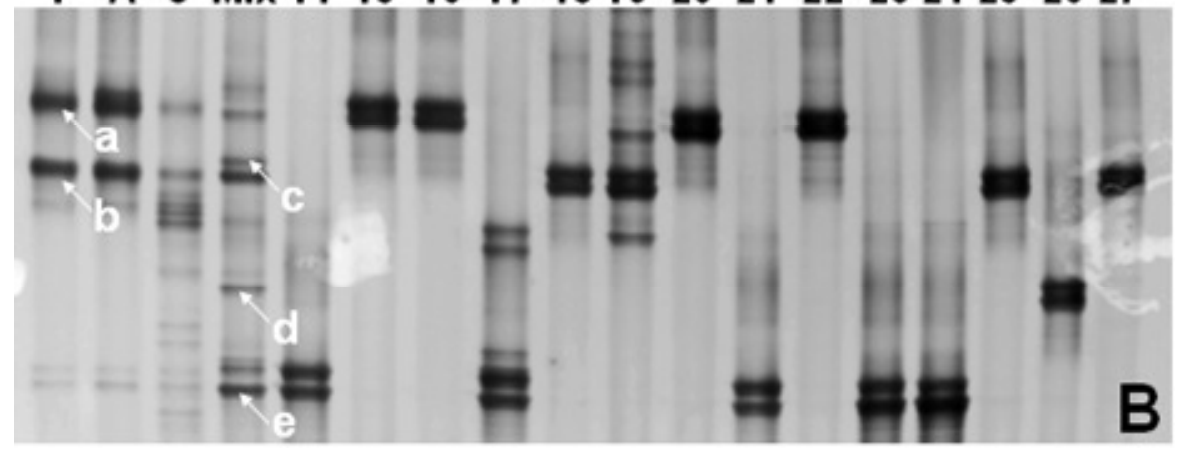

Figure 6. DGGE profiles of bacterial 16S rDNA gene fragments amplified from sourdough by using bacteria universal primer $27(\mathrm{~F}) / 338 f(R)^{+}$. F, Fabao; (A) Anqi; J, Distiller's grains; 1-27, bacterial strains isolated from sourdoughs. a-e, sequenced as L. plantarum, L. fermentum, L. fermentum, E. faecium and $P$. acidilactici.

name of strain 6. DGGE results indicated that strains 2,6 , 7, 10 and 14 belong to different strains and were sent to sequencing. Sequences were compared to the Genbank database with the BLAST program (Altschul et al., 1997) and the results are listed in Table 2. From the table, the strains selected belong to L. plantarum, S. thermophilus, Lactobacillus paracasei, Bacillus cereus and Lactobacillus delbrueckii, respectively.

\section{The microbial screening from sourdoughs}

Sourdough, in terms of their microbial composition, is a complex biological system where fundamental interactions between LAB and yeasts take place (Collar, 1996). In this study, the PCR-DGGE method was applied in microbial screening which decreased the chance of isolating the duplicate strain. At first, 27 bacteria and 10 fungi were isolated from sourdough by using culture-dependent method and then preliminary screening was performed by using PCR-DGGE. In order to identify the dominant microorganisms in these three basic sours (Fabao, Anqi and Distiller's grains), their DNAs as well as the mixture of all the isolates were extracted and this served as the DGGE markers (Figures 6 and 7). According to the band number and locations, the bacteria and fungi were divided into 13 (Table 3) and 2 groups and then were identified by using bacterial total length primer $27(\mathrm{~F}) / 1492(\mathrm{R})$ (Lane, 


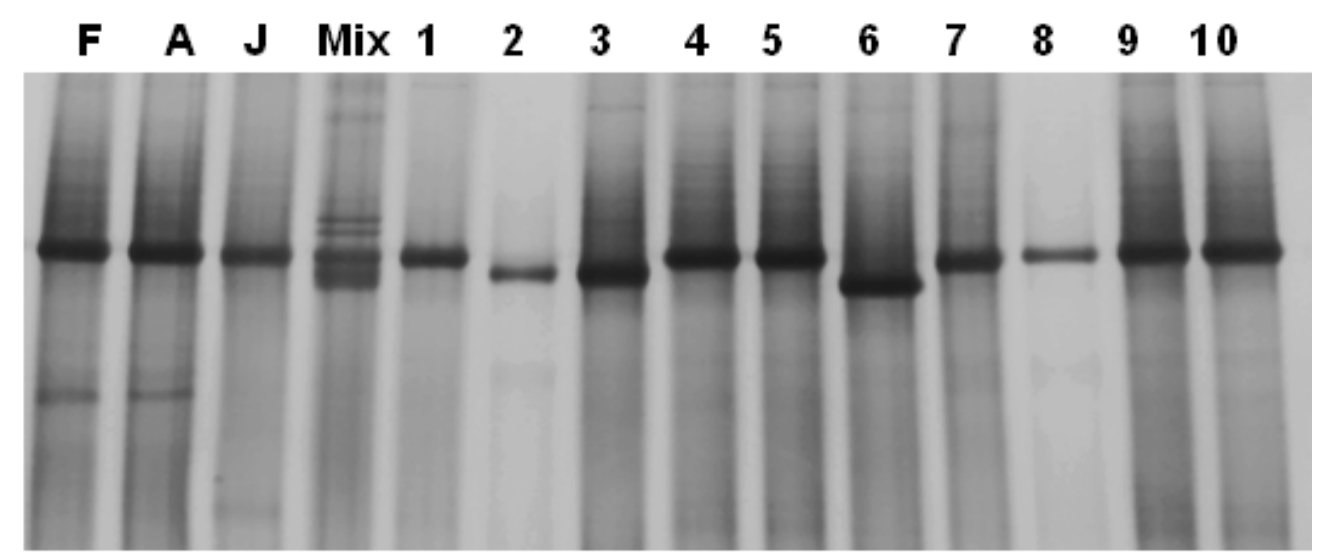

Figure 7. DGGE profiles of fungi 18S rDNA gene fragments amplified from sourdough by using fungi universal primer F390 (F)/FR1 (R) ${ }^{+}$. F, Fabao; A, Anqi; J, Distiller's grains; 1-10, fungi isolated from sourdoughs.

Table 3. 16S rDNA sequencing results of bacteria in sourdough distinguished by denaturing gradient gel electrophoresis (DGGE) method.

\begin{tabular}{clcc}
\hline Strain no. & Closest relative & Similarity $(\%)$ & GeneBank no. \\
\hline $1,18,25$ & Lactobacillus fermentum & 100 & HM218438.1 \\
$2,3,7,15,16,20,22$ & Lactobacillus plantarum & 99 & HM218754.1 \\
$4,12,13,19$ & Lactobacillus fermentum & 100 & HM218438.1 \\
5 & Lactobacillus reuteri & 98 & HM218416.1 \\
6 & Bacillus subtilis & 99 & HQ153100.1 \\
8 & Enterococcus faecium & 99 & HM218625.1 \\
9 & Staphylococcus sp. & 99 & HQ141278.1 \\
10 & Weissella confusa & 98 & GU369778.1 \\
11 & Weissella confusa & 100 & HM218434.1 \\
25,27 & Lactobacillus plantarum & 100 & HQ141913.1 \\
17 & Pediococcus acidilactici & 100 & GU904688.1 \\
$14,21,23,24$ & Pediococcus acidilactici & 100 & GU904688.1 \\
26 & Pediococcus pentosaceus & 100 & HQ141913.1 \\
\hline
\end{tabular}

1991) and fungi total length primer NS1 (F)/ FR1 (R) (Vainio and Hantula, 2000), respectively.

Figure 6 a and $b$ shows that, 13 strains were obtained by using DGGE method from 27 isolate and 9 different bacteria were identified (Table 3 ) by sequencing. In Figure 7 , the DGGE results indicated that, only Kluyveromyces lactis (2, 3 and 6) and Saccharomyces cerevisiae $(1,4,5,7,8,9$ and 10) were obtained and $S$. cerevisiae was the dominant fungi in these three basic sours.

\section{DISCUSSION}

For microbiologists, it is a hard work to identify the large number of isolates. Above all, the duplicate strains existing in isolates result in a waste of time and money. In this study, the DGGE method was applied in microbial screening based on its basic principles and was proved to be a powerful tool in identifying the duplicate strains.

At present, DGGE analysis is one of the most suitable and widely applied methods to study complex bacterial communities originating from various environments (Muyzer, 1999). But, all kinds of methods have specific limitations that need careful evaluation. Environmental samples represent a complex matrix, including various proteins, fats, enzymes and polysaccharides. In addition, various other unknown substances, may interfere and act as inhibitors in the following analyses (Malik et al., 2008; O'Callaghan et al., 2010; Rudi et al., 2005; Wilson, 1997). Moreover, heterogeneous sequencing gives rise to more than one band on DGGE and thereby, overestimates the community diversity (Ast and Dunlap, 2005; Min-juan and Zhi-yue, 2008; Zoletti, et al., 2010). Also, the fragments 
studied by DGGE are limited to a length of 500 base pairs (bp) for the decreased resolution of DNA in the gel (Myers et al., 1985) and it is a relatively short sequence for database comparison, though the V3-region is known to have a high grade of resolution and to be highly variable (Jensen et al., 2004).

In this study, our objective is just to clarify the duplicate microorganisms, which can ignore the disadvantage of more than one band on DGGE for single strain caused by heterogeneous. Take the sourdough for example; 13 different strains with the same band number and locations were distinguished from 27 isolates, but the experiences indicated that, if the bacterial dominant bands in DGGE lanes were consistent, they can be considered as the same strain. For strains 10 and 11, though they possessed different band number, their dominant bands are consistent and confirmed as the same strain by sequencing. The same results had been obtain among strains 1, 18, 25 and 4, 12, 13, 19; 2, 3, 7, 15, 16, 20, 22 and 25,$27 ; 17$ and $14,21,23,24$. The results also indicated that, DGGE can totally classify all the isolates into 9 different strains, which was consistent with the sequencing results. Also, the bands of DGGE markers showed that, the L. plantarum (a) and Lactobacillus fermentum (b) were the dominant strains in Fabao, Anqi and Distiller's grains.

Currently, reliable identification of microorganisms remains a point of crucial importance. In this study, the application of PCR-DGGE method in microbial screening had been successfully performed in viili and sourdoughs, which reduces the work load for researchers and improves the identification accuracy and efficiency. Above all, just like the applications of DGGE in monitoring the microbial diversity, this microbial screenings method could be applied in all kinds of fields on microorganisms.

\section{ACKNOWLEDGEMENTS}

The viili starter was a generous gift from Dr. Yinghua Lu (Xiamen University) and this project was sponsored by the National High Technology Research and Development Program ("863"Program, 2008AA10Z337) and the National Basic Research Program ("973" Program, 2005DKA21202 ) of China.

\section{REFERENCES}

Altschul S, Madden T, Schaffer A, Zhang J, Zhang Z, Miller W, Lipman D (1997). Gapped BLAST and PSI-BLAST: a new generation of protein database search programs. Nucleic Acids Res., 25: p. 3389.

Ast J, Dunlap P (2005). Phylogenetic resolution and habitat specificity of members of the Photobacterium phosphoreum species group. Environ. Microbiol., 7: 1641-1654.
Bastias B, Anderson I, Xu Z, Cairney J (2007). RNA-and DNA-based profiling of soil fungal communities in a native Australian eucalypt forest and adjacent Pinus elliotti plantation. Soil Biol. Biochem., 39: 3108-3114.

Collar C (1996). Review: Biochemical and technological assessment of the metabolism of pure and mixed cultures of yeast and lactic acid bacteria in breadmaking applications/Revisi" ${ }^{\circledR} \mathrm{n}$ : Aspectos bioqu"-amicos y tecnol" $\circledast$ inicos del metabolismo de cultivos puros y mixtos de levaduras y bacterias "\$cido I" $\pitchfork$ cticas en panificaci" $\AA^{\circledR}$. Food Sci. Technol. Int., 2: p. 349.

Endo A, Futagawa-Endo Y, Dicks L (2009). Lactobacillus and Bifidobacterium Diversity in Horse Feces, Revealed by PCR-DGGE. Curr. Microbiol., 59: 651-655.

Fujimori F, Okuda T (1994). Application of the random amplified polymorphic DNA using the polymerase chain reaction for efficient elimination of duplicate strains in microbial screening. J. Antibiot. 47: 173-182.

Giraffa G (2004). Studying the dynamics of microbial populations during food fermentation. Fems Microbiol. Rev., 28: 251-260.

Hovda M (2007). Application of PCR and DGGE to characterise the microflora of farmed fish.

Hovda M, Lunestad B, Fontanillas R, Rosnes J (2007). Molecular characterisation of the intestinal microbiota of farmed Atlantic salmon (Salmo salar L.), Aquaculture, 272: 581-588.

Jacobsen N (1999). The influence of commonly used selective agents on the growth of Listeria monocytogenes. Int.ernational J. Food Microbiol., 50: 221-226.

Jensen S, vres L, Bergh, Torsvik V (2004). Phylogenetic analysis of bacterial communities associated with larvae of the Atlantic halibut propose succession from a uniform normal flora. Syst. Appl. Microbiol., 27: 728-736.

Lane D (1991). 16S/23S rRNA sequencing. Nucleic Acid Techniques in Bacterial Systematics (Stackebrandt E \& Goodfellow M, eds). J. Wiley \& Sons, Chichester, 115"C-175.

Liu C, Yang J, Wu G, Zhang S, Li Z, Guo J (2010). Estimation of dominant microbial population sizes in the anaerobic granular sludge of a full-scale UASB treating streptomycin wastewater by PCR-DGGE. World J. Microbiol. Biotechnol., 26: 375-379.

Lubbs D, Vester B, Fastinger N, Swanson K (2009). Dietary protein concentration affects intestinal microbiota of adult cats: a study using DGGE and qPCR to evaluate differences in microbial populations in the feline gastrointestinal tract. J. Anim. Physiol. Anim. Nutr. 93: 113-121.

Malik S, Beer M, Megharaj M, Naidu R (2008). The use of molecular techniques to characterize the microbial communities in contaminated soil and water. Environ. Int., 34: 265-276.

Meroth CB, Walter J, Hertel C, Brandt MJ, Hammes WP (2003). Monitoring the bacterial population dynamics in sourdough fermentation processes by using PCR-denaturing gradient gel electrophoresis. Appl. Environ. Microbiol., 69: 475-482.

Min-juan X, Zhi-yue W (2008). DGGE and its Application in Microecology. Acta Ecologiae Animalis Domastici, 29: 147-150.

Muyzer G (1999). DGGE/TGGE a method for identifying genes from natural ecosystems. Curr. Opin. Microbiol., 2: 317-322.

Myers R, Fischer S, Lerman L, Maniatis T (1985). Nearly all single base substitutions in DNA fragments joined to a GC-clamp can be detected by denaturing gradient gel electrophoresis. Nucleic Acids Res., 13: p. 3131.

O'Callaghan M, Gerard E, Carter P, Lardner R, Sarathchandra U, Burch $G$, Ghani A, Bell N (2010). Effect of the nitrification inhibitor dicyandiamide (DCD) on microbial communities in a pasture soil amended with bovine urine. Soil Biol. Biochem., 42: 1425-1436.

Rudi K, Skanseng B, Dromtorp S (2005). Explorative screening of complex microbial communities by real-time 16S rDNA restriction fragment melting curve analyses. Biol. Tech., 39: p. 116.

Sambrook J, Russell D (2001). Molecular cloning: a laboratory manual. CSHL press. 
Simpson P, Fitzgerald G, Stanton C, Ross R (2004). The evaluation of a mupirocin-based selective medium for the enumeration of bifidobacteria from probiotic animal feed. J. Microbiol. Methods, 57: 9-16.

Temmerman R, Huys G, Swings J (2004). Identification of lactic acid bacteria: culture-dependent and culture-independent methods. Trends Food Sci. Technol., 15: 348-359.

Todorov A, Engell A (2008). The role of the amygdala in implicit evaluation of emotionally neutral faces. Social Cognitive Affective Neurosci., 3: 303.

Vainio E, Hantula J (2000). Direct analysis of wood-inhabiting fungi using denaturing gradient gel electrophoresis of amplified ribosomal DNA. Mycol. Res., 104: 927-936.

Wang S, Chen H, Liu J, Lin Y, Chen M (2008). Identification of yeasts and evaluation of their distribution in Taiwanese Kefir and Viili starters. J. Dairy Sci., 91: 3798-3805.

Wilson I (1997). Inhibition and facilitation of nucleic acid amplification. Appl. Environ. Microbiol., 63: p. 3741.
Yaffe M, Schatz G (1984). Two nuclear mutations that block mitochondrial protein import in yeast. Proc. Natl. Acad. Sci. USA., 81: p. 4819.

Zoetendal E, Akkermans A, De Vos W (1998). Temperature gradient gel electrophoresis analysis of 16S rRNA from human fecal samples reveals stable and host-specific communities of active bacteria. Appl. Environ. Microbiol., 64: p. 3854.

Zoletti G, Carmo F, Pereira E, Rosado A, Siqueira Jr. J, dos Santos K (2010). Comparison of endodontic bacterial community structures in root canal-treated teeth with or without apical periodontitis. J. Med. Microbiol., 159: p. 1360. 